\title{
How to use Socratic questioning in order to promote adults' self-directed learning
}

Citation for published version (APA):

Katsara, O., \& De Witte, K. (2019). How to use Socratic questioning in order to promote adults' selfdirected learning. Studies in the Education of Adults, 51(1), 109-129.

https://doi.org/10.1080/02660830.2018.1526446

Document status and date:

Published: 01/01/2019

DOI:

10.1080/02660830.2018.1526446

Document Version:

Publisher's PDF, also known as Version of record

Document license:

Taverne

Please check the document version of this publication:

- A submitted manuscript is the version of the article upon submission and before peer-review. There can be important differences between the submitted version and the official published version of record.

People interested in the research are advised to contact the author for the final version of the publication, or visit the DOI to the publisher's website.

- The final author version and the galley proof are versions of the publication after peer review.

- The final published version features the final layout of the paper including the volume, issue and page numbers.

Link to publication

\footnotetext{
General rights rights.

- You may freely distribute the URL identifying the publication in the public portal. please follow below link for the End User Agreement:

www.umlib.nl/taverne-license

Take down policy

If you believe that this document breaches copyright please contact us at:

repository@maastrichtuniversity.nl

providing details and we will investigate your claim.
}

Copyright and moral rights for the publications made accessible in the public portal are retained by the authors and/or other copyright owners and it is a condition of accessing publications that users recognise and abide by the legal requirements associated with these

- Users may download and print one copy of any publication from the public portal for the purpose of private study or research.

- You may not further distribute the material or use it for any profit-making activity or commercial gain

If the publication is distributed under the terms of Article $25 \mathrm{fa}$ of the Dutch Copyright Act, indicated by the "Taverne" license above, 


\title{
How to use Socratic questioning in order to promote adults' self-directed learning
}

\author{
Ourania Katsara $^{a}$ (D) and Kristof De Witte ${ }^{b, c}$ (D) \\ ${ }^{a}$ Department of Business Administration of Food and Agricultural Enterprises, University of Patras, \\ Agrinio, Greece; 'beuven Economics of Education Research, School of Business and Economics, \\ University of Leuven, Leuven, Belgium; 'Top Institute for Evidence Based Education Research, \\ University of Maastricht, Maastricht, The Netherlands
}

\begin{abstract}
This article discusses the teachers' role in self-directed learning (SDL) - a central concept in adult education. We explore the use of Socratic questioning to develop critical thinking, which is the outcome of SDL in problem-based learning (PBL). In particular, we analyse 11 adult learners' reflective journals in relation to a Socratic seminar. Findings showed that adult learners value the mutual relationship between the learner and the teacher in managing the learning process. In addition, we suggest a teaching approach where Socratic questioning can facilitate students' SDL. We conclude with implications on its use as a means to initiate the learning goals of a PBL tutorial.
\end{abstract}

\section{KEYWORDS}

Adult learning; self-directed learning (SDL); critical thinking; Socratic questioning; problem-based learning $(\mathrm{PBL})$

\section{Introduction}

Knowles et al. (1988) argued that teachers of adults face certain challenges that differ from those of primary school teachers. This is reflected in the study of 'andragogy'. Knowles (1980, p. 43) defined andragogy as 'the art and science of helping adults learn, in contrast to pedagogy as the art and science of teaching children'. Knowles (1984) argued that a pedagogue would want the learner to be dependent on the teacher while an andragogue would want to encourage the learner to be autonomous being a facilitator in learning instead of simply transmitting and evaluating knowledge. In addition, Knowles (ibid) asserts that adults have more experiences than children and adults have created pre-established beliefs. Knowles notes that experience is the most important issue during learning since adults are focusing more on the process rather than the content being taught.

While Knowles' 'andragogy' (1970) is still valid and useful, it has not reached the status as a theory of adults' learning or theory of teaching (Knowles et al. 1998; Merriam et al. 2007). A general criticism of andragogy is that there is limited

CONTACT Ourania Katsara okatsara@upatras.gr E Department of Business Administration of Food and Agricultural Enterprises, University of Patras, Georgiou Seferi 2, 30100, Agrinio, Greece.

This article has been republished with minor changes. These changes do not impact the academic content of the article. 
empirical evidence produced and as a result, andragogy lacks the basic characteristics of a science (Rachal 2002). Henschke (2015) mentions that for some, it has been used as a set of tools in order to design strategies and methods to help adults learn. Based on Knowles' assumptions of andragogy scholars argue that there are specific teaching methods that support adult learning. Jarvis (2004, p. 153) claims that teachers should facilitate learning by guiding students through the learning process but without dictating the outcome of the experience. Jarvis also believes that teachers should promote autonomy by means of freedom of pace, choice, method, content or assessment. For example, students should be free to choose what they learn. Rubenson (2011, p. 57) argues that teachers should share power and decision-making roles with their students. For example, teachers should avoid providing right answers and involve students in managing the learning environment.

The main implication is that there are different perspectives on teachers' role or teaching orientations (Daley 2003); therefore, a teacher of adults should be able to use different teaching strategies (Larsen 2012). Larsen (ibid) argues that even though adults are self-directed and responsible for their own learning, interchange of experiences in teaching might be intrusive indicating that the teacher should be in control of acknowledging adults' personal and/or cultural attributes.

For example, a survey conducted by Katsara (2014) demonstrated that the Greek students' self-assessment responses to the use of certain strategies when dealing with exam questions were not consistent. Based on Ramsden's (1997) argument, which dictates that the learner's experience of evaluation and assessment determines the way in which the student approaches (future) learning, the main implication of this study is that Greek students need more clarification on the didactic purposes of these assessments before engaging in them. It is argued, therefore, that for Greeks, explaining teaching procedures in a University context appears to be vital. This implies the teacher's role seems to be indispensable in smoothing the learning process.

The above discussion reflects the arguments put forward by Merriam et al. (2007, p. 103) who argue that 'there are a number of theories, models, and frameworks, each of which attempts to capture some aspect of adult learning'. Garrison (1992) argues that a coherent framework for adult education should consider an approach that attempts to unify existing frameworks. He suggests the development of a critical thinking learning model that includes the concept of self-directed learning (SDL). This is also supported by Tusting and Barton (2006), who maintain that adults are self-directed learners and learn through critical reflection on their experience, which sees learning as individually and/or socially transformative.

\section{Purpose of the research}

The purpose of this survey is to explore a response to the views discussed above by exploring the work by Wang et al. (2008), who analyzed the thinking structure and philosophical background of problem-based approach (PBL) through the educational ideas of Socrates. Wang et al. (2008) argued that Socrates' educational method is a good example and solution for training critical thinking, which is the desired outcome of PBL (Oermann 2004). Hmelo-Silver and Eberbach (2012) argue that one 
of the features of PBL is SDL, which refers to the process where students are asked to pursue research to answer the questions that can provide solutions to the original problem presented to them. This process implies that students need to critically evaluate information and the use of Socratic questioning could assist them to do so. As Paul and Elder (2007) stress, both critical thinking and Socratic questioning share a common end. The goal of critical thinking is to establish an inner voice of reason while Socratic discussions cultivate this inner voice through a focus on self-directed disciplined questioning (ibid). Therefore, in this sense, based on the suggestions made by Garrison (1992), Tusting and Barton (2006), Wang et al. (2008), and Paul and Elder (2007) adult learning within a PBL and Socratic questioning context places emphasis on transformational learning, which according to Mezirow (1991), is changing our beliefs or attitudes in our perspective, in order to make sense of our experiences. Mezirow (1991, p. 14) argues that the ability to reflect critically is itself developmental while the outcome, a changed perspective is developmental in the sense that we are able to 'deal with a broader range of experience'.

This study discusses the influence of Socratic questioning on adult learners' development of transformational learning arguing that its use in defining the learning objectives of a seminar could trigger the cognitive process of learning referring to inner meaning and reflection (Merriam 2004). The study contributes to the literature that examines adult learners' critical thinking in SDL since it underlines the crucial role of the student-teacher relationship in the management of the learning process. Existing literature indicates that, for example, in PBL depending on how learning objectives are defined, students' independent seeking and synthesis of information sources might be purposeful or may be insufficient (Wilkes and Srinivasan 2017). Lloyd-Jones and Hak (2004) found that in an integrated PBL curriculum in a British institution, student learning was not self-directed but was socially agreed among the peer group and/or directed by the resources given by the faculty. Therefore, this study is an example of Garrison's (1992) suggestion in the sense that his critical thinking model that includes the concept of SDL encompasses the use of Socratic questioning, which promotes critical thinking within a specific teaching method, the PBL approach. In other words, the study contributes to providing a possible extension of adult learning theory within specific teaching approaches and models, in this case, within PBL. The key research question of this article was to explore Socratic questioning in and out of a PBL classroom of adult learners.

The remainder of the article examines the use of Socratic questioning to develop critical thinking, which is the outcome of SDL in problem-based learning (PBL). In particular, an analysis of 11 adult learners' reflective journals in relation to a Socratic seminar is discussed. It is shown that adult learners value the mutual relationship between the learner and the teacher in managing the learning process. A suggestion of a teaching approach is offered where Socratic questioning could facilitate students' SDL.

\section{Literature review}

The search for the review used the following digital databases: Educational Resource Information Centre-ERIC, web of science, and the following search engines, Google, 
Google scholar, altavista. Also, full text journals were accessed from University of Maastricht online library.

In the current review, the focus was on the ways that teachers could use in order to facilitate SDL learning for adults within a PBL environment. The other components of the PBL were excluded from the search. It was decided, therefore, to gather available literature to build on Wilkes' and Srinivasan's (2017) remarks, Wang's et al. (2008) work and Wang's et al. (2008) arguments. The variables selected, therefore, were related to teaching strategies for adult learners. Certain keywords within the above variable framework used in this study were: SDL, PBL, Socratic questioning, andragogy. The articles selected for the study must have been written in English and published in peer-reviewed documents.

\section{The Socratic method}

The Socratic method originated from the Greek philosopher Socrates, although its definition is elusive since the only documentation of Socrates' teaching is in Plato's dialogues (Burbules and Bruce 2001). Some argue that Socratic questioning means applying certain types of questions such as clarification questions and questions probing assumption (Yang et al. 2005; Paul and Elder 2008; Knežić et al. 2010). Morrell (2004) stipulates that Socratic questioning means 'elenchus', a sort of cross-examination in which questions are asked about beliefs in such a way as to reveal contradictions. Robinson (1971) suggests that 'elenchus' works by making students admit their ignorance. 'Elenchus' is applied to students by means of probing each response from students and examining whether the entire set of beliefs held by them is mutually consistent (Robinson 1971). This for Socrates is far better than possessing untrue beliefs (ibid). The natural outcome of 'elenchus' according to Matthews (1999) is 'aporia' or confusion and as Boghossian (2012) argues, Socrates' point is not to cause perplexity for its own sake but to arouse curiosity about what is untrue; there is no reason for them to think otherwise unless someone points out their mistaken belief. In this state, learners realize that they have to seek new knowledge (Vlastos 1971). Matthews (1999) states that 'aporia' is used as a means not to merely transport knowledge from the teacher to the student but to puzzle both to continue the search, portraying a thinking disposition rather than a methodology.

The Socratic method of inquiry promotes self-directed learning and critical thinking (Copeland 2005; Hendricson et al. 2007; Wang 2010). It is argued that the Socratic method of inquiry is an inspiring process since the questions are asked both to draw individual answers and encourage individuals' fundamental insight into the issue under discussion. This form of inquiry stimulates critical thinking illuminating ideas (Wang 2010, p. 5). In addition, Wang (ibid) argues that this method is designed to bring out definitions implicit in the interlocutors' beliefs, challenges accuracy and completeness of thinking and helps individuals enhance their understanding in order to move towards their ultimate goal.

In a Socratic seminar, students are asked to think carefully and answer open-ended questions to texts that foster controversy about issues and values (Adler 1984; Roberts and Billings 1999). The purpose of it is a dialogic process in order to enhance 
understanding of the text as interpretations and perspectives are explained and discussed (Pihlgren 2014). This involves the modification or solidification of synthesis, evaluation and elaboration of the text (Paideia Centre 2002). Philgren argues that the key in classroom discussion is to refrain from seeking consensus and to cultivate openness towards distinction. It is important to note that according to Copeland (2005), Socratic seminars are student-driven conversations aiming to explore deeper understandings about the truths of the world with no definite beginning or end. Therefore, it is the students' responsibility to direct and develop the conversation by talking with each other and not with the teacher. The teacher acts as a facilitator clarifying issues through questions but does not contribute substantially to the conversation (Ball and Brewer 2000, p. 1).

\section{Problem based learning (PBL)}

Silén and Uhlin (2008) argue that PBL was primarily modelled on the curriculum at McMaster University, Hamilton, Canada and Maastricht University, the Netherlands. This curriculum was based on Knowles' (1975) andragogy and self-directed learning and the ideas of the application of PBL developed by Barrows and Tamblyn (1980).

In PBL, small groups of students meet two or three times a week under the guidance of a tutor (Barrows 1985; 2000; Hmelo-Silver 2004; Hmelo-Silver and Barrows 2006; Schmidtet al. 2009; Skinner et al. 2015). Initially, they receive a problem, which is typically a neutral description of a phenomenon that needs to be explained. Students' discussions about the problem base the generation of their own learning goals for subsequent self-directed learning (SDL). After a period of self-study, students meet again to share what they have learned about the topic and test whether their new understanding of the problem is more accurate than before. Once students are satisfied with the learning outcomes, they engage with a new problem and the cycle starts again.

The literature indicates that in PBL, the SDL component has been addressed as general skills separated from context being defined as individual characteristics (Silén and Uhlin 2008). Miflin (2004) underlined the notion of self and management of the learning situation arguing that not much attention has been paid to the internal processes of learning involving responsibility and independence. Kamin et al. (2001) argued that SDL on its own is not sufficient to describe critical thinking. They consider that SDL is associated to a large extent to an external management function and critical thinking is associated with the internal cognitive process. The role of the PBL facilitator is to develop and encourage learners' sense of responsibility and selfregulatory behavior. The ability to collaborate and be self-directed is necessary for critical thinking and it could be realized by integrating individual responsibility for learning and sharing control. This reflects the argument put forward by Neville (1999), who maintains that is fallacious to assume that to be successful, the entire educational process of PBL must be entirely self-directed.

Other educational processes are also crucial to the successful use of PBL (Milligan 1999). For example, 'situational interest' might be critical in students' development of critical thinking. Schmidt et al. (2011) assert that situational interest is not a stable dispositional form of interest but is situationally aroused by an intriguing puzzle or 
problem. Rotgans and Schmidt (2012) in a survey found that when students were presented with a problem in a $\mathrm{PBL}$ learning environment at university, their 'situational interest' increased. Students' awareness of their lack of knowledge is responsible for igniting curiosity (Norman and Schmidt 1992). Therefore, as Litman (2008) argue, the desire for new knowledge is aroused by ambiguous statements and unsolved problems. However, Lim (2011) adds that even though students develop a good degree of critical reflection in a PBL environment, this development either levels out or show signs of decline as students' progress through the years. Kember et al. (2000, p. 391) found similar results suggesting that critical reflection 'requires a major change in perspective, which is a difficult, lengthy and often painful process'. In light of this, Lim suggested that institutions should consider other ways of doing PBL in order to push them toward deeper levels of reflection.

\section{Socratic questioning in PBL}

The Socratic method of 'elenchus' has been regarded as perhaps one of the earliest teaching strategies ever described in education history (Miller 2008; Wang 2010). This strategy is still used today as a dialectic method of teaching that involves dialogue and questioning, emphasizing the exchange of ideas and suppositions that then transforms knowledge itself (Miller 2008, p. 963). Socratic questioning is inherent in PBL learning since students question their knowledge when they confront new problems (Rogal and Snider 2008). Banning (2005) argued that in Socratic questioning, the teacher elicits responses from the student through questions aiming at probing the layers upon which knowledge is built. This is a critical teaching method because the teacher's role is not to reveal related information to the students (Henson 2003).

Oermann (2004) asserted that during the questioning process, students are encouraged to draw on past knowledge and experience to work out answers by themselves. This acquired knowledge should be assessed for relevance being synthesized for use having the problem as a stimulus. This helps in the development of critical thinking, which is the desired outcome of PBL (ibid). Wang et al. (2008, p. 12), confirm that Socrates' educational method is a good example and solution for training critical thinking.

\section{Research method}

\section{Research setting: Overview of the implementation of the Socratic seminar}

The survey used the principles of the Socratic seminar developed by the National Paideia Centre (2002), which were based on the Paideia education program by Adler (1982). Students were asked to participate in a dialogue on education and discuss an article entitled 'Implementing tutorials within the context of an English for General Academic Purposes course at the University of Patras: A Preliminary study' (Katsara 2018).

According to the National Paideia Centre (2002), the seminar can be viewed as a five-stage cycle: (a) pre-seminar content activities, (b) pre-seminar process activities, (c) formal seminar dialogue, (d) post-seminar process activities and (e) post-seminar content activities. Adler (1982) suggested that there are three teaching practices named 'The Three Columns', which are employed in a Paideia seminar during this 
five-stage cycle. The Three Paideia Columns of instruction are designed to support specific aspects of learning: factual recall (didactic), intellectual skill development (coaching), conceptual understanding (seminar). Billings and Roberts (2003) note that the three columns are practiced in active synergy such that each of the three teaching modes reinforces the other two. The suggested approach starts with the teacher introducing to students some factual information (didactic). Then, coaching students' intellectual skills is followed by facilitating them with the use of open-ended questions to manipulate and apply the information (coaching). Finally, these questions help students talk about the ideas and values associated with the information (seminar).

This cycle was carried out as follows. First, on the day of the seminar, as part of the pre-seminar content activities, the teacher presented to students by the use of presentation software, relevant background information on the course content. This stage refers to the didactic column of instruction. Second, as part of the pre-seminar process activities, the teacher drew the students' attention to the process of it in order to prepare for the dialogue. The roles and expectations of both parties were introduced and the seminar ground rules were explained. Students were asked to wait for their turn to speak directly to one another building upon points made by their classmates and focusing on trying to interpret and understand the text. In addition, the group and personal participation goals for the seminar were set.

Third, regarding the seminar dialogue, the teacher facilitated the dialogue. National Paideia Centre (2002) state that the Paideia Seminar is an intellectual, collaborative dialogue facilitated with open-ended questions about a text. This dialogue allowed for students' participation while less teacher talk helped in setting the scene for a safe environment to take intellectual and social risks. Adler (1997) pointed out that the facilitator should maintain a position of being a more competent co-learner in the process. In addition, teachers should employ wait time and do not save the discussion from awkward silences (Chowning 2009). Billings and Roberts (2003) argue that during the seminar, the teacher as a coach gives supportive feedback while students practice the skill. On the day of the seminar, the teacher introduced the open-ended questions, which were grouped into three categories: (a) Opening questions with the purpose to get participants identify main ideas or values in the text, (b) core questions with the purpose to have participants closely analyze the details of the text and (c) closing questions with the purpose to encourage participants to personally synthesize and evaluate real-world applications. A full copy of the questions is offered in Appendix A. Billings and Roberts (2003) argue that opening and closing questions are called 'maieutic' questions associated with midwifery. These questions are meant to help student give birth to their own ideas, in other words, to elicit the participants' perspective. Core questions are what we think of as Socratic and focus on what is meant by the text often highlighting contradictions in one's thinking (ibid). The teacher also made some followup questions in response to participants' comments. The purpose was to facilitate the dialogue by asking questions that build and connect to what participants have said. Billings and Roberts (2003) suggested that these followup questions should be carefully selected, given the proper ratio of facilitator and participant talk time.

Fourth, the post-seminar process aimed at gathering students' self-assessment of the dialogue. At the end of the seminar, students were asked to fill in a reflective 
journal in order to self-assess their performance. Finally, the post-seminar content activities aimed at offering to students the opportunity to apply the ideas and values into their lives and current coursework. The self-reflective journal included an optional activity where students were asked to discuss in a paragraph the characteristics of a successful tutor in a problem-based tutorial since they are usually taught within a PBL environment. It was suggested that the ones who were interested to do this could do this activity at their earliest convenience and then they could send it by email to the teacher. Unfortunately, no student has sent a paragraph to the teacher, perhaps maybe because at that time, students were very busy being involved in projects assigned by the teachers of their programme.

\section{Participants}

Sampling for the selection of students completing the self-reflective journal was based on the notion of purposeful sampling. This involves identifying and selecting individuals or groups of individuals, who are especially knowledgeable about or experienced with a phenomenon of interest (Cresswell and Plano 2011). Patton (1990) argues that purposeful sampling is used for the selection of information-rich cases for the most effective use of limited resources. A category of purposeful sampling that encompasses this goal is sampling to achieve comparability (Patton 1990). This involves the goal of sampling to achieve comparability across different types of cases on a dimension of interest. A strategy used under this category that was particularly useful for the research was intensity sampling, which involves researching information-rich cases that manifest the phenomenon intensely but not extremely (Patton 1990). In the current study, the purpose was to categorise students' learning experiences using the typology of Socratic learners Meno students, Protagoras students, Gorgias students, Plato students when participating in a Socratic seminar.

Eleven adult students ( 6 female and 5 male) participated in the Socratic seminar. They were all over 30 years old, Dutch attending the second year of a two-year halftime research master and they were taught in a PBL environment. The students were informed about the seminar in several ways. The director of the program announced it orally explaining its structure and aim during the teaching session one month prior to the seminar. Furthermore, the seminar was included in the program, which the students receive a week before the session. Finally, the director of the program has also put an announcement on the electronic learning environment introducing the seminar and the reading assignment. It is also important to note that ethical approval from the director of the program was received prior to the commencement of the study.

\section{Instrument}

We used the reflective hand-written journal completed by the adult students at the end of the seminar in order to get insights into their experience participating in such a seminar. The questions of the reflective journal were based on the guidelines offered in the National Paideia Centre and on other reflection questions designed by other researchers available in the literature. A full copy of the reflective journal is offered in Appendix B. 


\section{Data analysis}

\section{Data collection}

On the day of the seminar, the adult students were asked to take part in a dialogue about Katsara's (2018) article. According to Ball and Brewer (1996, p. 33), the seminar text should (a) 'be filled with issues and ideas be worthy of discussion, (b) be open to multiple interpretations and (c) have sufficient complexity and ambiguity to sustain discussion and allow for exploration of concepts'.

After reading the article, the adult students were seated in a circle, having a conversation in order to arrive at a fuller understanding of the textual ideas and values of themselves and of each other in relation to the characteristics of a tutorial tutor, who better corresponds to Greek students' cultural background discussed in the article. As part of the debriefing process of the seminar, students were asked to fill in a reflective journal at the end of the seminar. It was also announced to them that this debriefing would be part of a research project in relation to the use of Socratic questioning as a teaching approach. All of the students agreed to fill in the reflective journal.

\section{Data analysis}

The analysis of the data was carried out in two phases. For the first phase of the analysis, Patton's (1990) content analysis was used where primary data are coded and categorized under different themes. For the second phase of the analysis, we analyzed the data on the basis of a typology of Socratic adult learners developed by Paraskevas and Wickens (2003) since the focus is on the adult learner. Lambert at al. (2014) argues that most adults can be highly segmented in terms of their responsibilities within learning environments. Therefore, understanding adults' views on their learning responsibilities are critical for their success.

It is important to note that we used the directed approach to content analysis, which aims to validate or extend conceptually a theoretical framework of theory (Hsieh and Shannon 2005). A directed approach to content analysis can provide predictions about the variables of interest or about the relationship among variables determining thus the initial coding scheme or relationship between the codes (ibid). A directed content analysis uses existing theory or prior research and researchers begin by identifying key concepts or variables as initial coding categories (Potter and Levine-Donnerstein 1999). Based on this, we used Paraskevas' and Wickens' (2003) characteristics of the four Socratic type learners as predetermined codes in order to highlight passages in the students' responses.

Paraskevas and Wickens (2003) developed a typology based on 1266 answers from participants in relation to their 'compatibility' with the Socratic method. The researchers named the clusters derived from the participants' classification of their answers after some typical participants in Socratic dialogues. Specifically, the typology consists of four adult learner types: the Meno type learner, the Protagoras type learner, the Gorgias type learner, and the Plato type learner. Based on participants' responses Paraskevas and Wickens (2003, p. 8-10) described the profile of each of the four adult learner types and identified certain characteristics of the four types of learners. 
Specifically, Meno is a slave boy, a young adult whom Socrates had one of the most interesting dialogues. Throughout the dialogue, Socrates's power of teaching a slave boy is evident. Meno appears to be incapable of using his knowledge since he repeats what Socrates say or is led to say what Socrates wants to hear. This learner type is dependent on the lecture-type of teaching where explicit answers are given to questions by an authority figure. These learners are usually passive having a negative reaction to the 'questioning technique'.

Protagoras seemed to have restricted knowledge to sense experience, but he thought that perception by the senses was true. The Protagoras type learners are the ones who respond to motivational techniques. These learners need a directive and supportive teacher, who can enhance their willingness to take part in the discussion keeping their enthusiasm about it. However, these learners can be sensitive to criticism when their prior knowledge is limited on the topic under discussion becoming negative in a Socratic environment.

Gorgias believed that rhetoric is the gem of all arts. A layman who is clever enough and a skillful rhetoric could win even the specialist. The Gorgias type learners are the ones who have the skills and perhaps some knowledge to visualize themselves as 'owners of their fate'. However, they need a guide to help them develop their confidence and once this is achieved, they would be ready to explore topics by themselves. The dialogue should focus on the development of critical thinking rather than on the learning theories and concepts.

Plato was the best student of Socrates. He managed to develop his own doctrines being somewhat reluctant to attribute to his teacher. The Plato type learners are mature in educational terms and seem to be 'in charge' of their learning.

\section{Results}

\section{First phase: General interpretation}

\section{Students' opinions about the seminar}

Reflections by five students indicated that they seemed to have realized that the Socratic seminar was a different approach that aimed to elicit their views in a safe environment, which embraces the diversity of views. Comments included:

\section{Teaching approach. 'It was very open'.}

'It was a new approach'.

'It was nice that there was an active process going on'.

However, it is shown that students interacted with the Socratic seminar in line with their instructional conceptions rather than the intentions of the teacher. According to Elen and Lowyck (1999), learners' instructional conceptions refer to students' ideas about how (innovative) instructional interventions relate to their learning.

In $\mathrm{PBL}$, students are presented with a problem in order to activate their prior knowledge (Schmidt et al. 2011). Comments reflected students' expectations to be given the topic under discussion:

Students' expectations. 'This seminar did not meet my expectations and I did not like because of the subject, the unclear goal of the seminar and unclear expectations for us (the students)'. 
Table 1. Students' personal goals.

\begin{tabular}{lr}
\hline Personal goal & No. \\
\hline To make clear accurate statements & 1 \\
To refer to the text & 6 \\
To comment on positive/negative implications on the topic & 2 \\
To add a global/holistic interpretation to a previous statement & 2 \\
\hline
\end{tabular}

These comments reflect students' expected misinterpretation of the nature of a Socratic seminar and the role of the teacher as a facilitator during one since this was the first time these students participated in a Socratic seminar. In addition, four students indicated that they wanted to know a reason for learning something that makes sense to them reflecting their adult attitude to learning (Knowles 1984):

'The way we were introduced to take part was not clear to me! Maybe an introduction or an assignment beforehand could have made it clearer to me'!

\section{Students' achievement of their personal goals}

The findings indicate, as shown in Table 1 below, that the majority of the students (6) chose to refer to the text as their personal goal.

Reasons for not achieving the goal. More than half of the students (7) did not achieve their personal goal, mainly because they have not prepared well for the seminar:

'I have not read the article beforehand, so my input was low'.

Three students mentioned that they partly achieved their goal because the context in which the seminar took place was not clear (i.e. uncertainty on the topic of the seminar and less teacher involvement) and they had different expectations while only one reported that she achieved her personal goal:

'I tried to be specific and accurate but found it hard to discuss things due to the lack of information on the set up of the lecture (i.e. not fully prepared)'.

'I tried to participate in the discussion but I prepared the article in another way'.

These comments might show that students interacted with the instructional intervention (i.e. the Socratic seminar) in accordance with their instructional conceptions rather than the intentions of the teacher of the instructional intervention. Students misunderstood the learning context within which a Socratic seminar takes place.

\section{Students' self-assessment during seminar}

The majority of the students (8) reported that they never made accurate statements indicating that they experienced difficulties in participating in the Socratic seminar where they should articulate and clarify their positions. Articulating and clarifying their opinion involves an understanding of the complexity in issues having the opportunity to share individual perspectives working towards a new synthesis of knowledge and understanding (Pihlgren 2007).

However, seven students responded that they sometimes commented on positive/ negative implications on the characteristics of a tutorial tutor, who better corresponds to Greek students' cultural background. This finding might imply that when students are encouraged to reiterate the need for evidence, then this might be a useful strategy to help/encourage them to express their point of view. In addition, students' self-report 
Table 2. Students' self assessment during seminar.

\begin{tabular}{lccc}
\hline Personal goal & Never No. & Sometimes No. & Always No. \\
\hline I made clear accurate statements & 8 & 3 & 0 \\
I referred to the text & 4 & 6 & 1 \\
I commented on positive /negative implications on the topic & 4 & 7 & 0 \\
I added a global/holistic interpretation to a previous statement & 6 & 5 & 0 \\
\hline
\end{tabular}

on relating the text ideas to issues in their lives show that five students sometimes added a global interpretation to a previous statement indicating that the discussion motivated them to talk about their life experiences in relation to teaching students from different cultural backgrounds (Table 2).

These self-assessments indicated that students exhibited some adult learner characteristics within the andragogy model proposed by Knowles (1984). Students appeared to be motivated to participate by commenting on both positive and negative implications of the topic under discussion. Commenting on both positive and negative aspects of an idea is valuable in the academic world since this analysis can clarify a point encouraging deeper thought and therefore, driving research forward. The analysis of the individual interpretation of students' comments discussed in the next section indicates that their thoughts support the idea of opposing ideas to transformational learning. Also, students appeared to be motivated to learn by talking about their life experiences. This heterogeneity in the group of adults appeared to be a rich resource for learning by self and others.

\section{Students' views on what to work in a future seminar}

Students acknowledged that personal responsibility is essential to the success of the seminar. Comments in relation to suggestions for future seminars included:

Future suggestions for Socratic seminars. 'Better preparation for this type of seminars'.

'Asking the teacher what to expect'.

'Refer to text more'.

These comments might imply that the kind of interjection a teacher makes might imply that success is determined by the students' preparation to interact with the text and each other.

\section{Second phase: Individual interpretation}

Students' answers showed that they exhibited some characteristics of Paraskevas' and Wickens' (2003) adult learners' typology.

\section{Meno learner characteristics}

Students exhibited Meno learner characteristics and their comments showed that their reaction to the questioning technique was rather negative. Seven students felt confused about the purpose of the conversation:

Purpose of the conversation. 'No, it's still a bit confusing as to what is the goal of the study'. 
'I tried to be specific and accurate but found it hard to discuss things due to the lack of participation of the group teacher'.

Students' comments on whether they achieved their personal goal and understood the text (data) better at the end of the seminar indicated the effect of 'elenchus'. Comments made by six students showed that students felt uncertain on the argument put forward in the text, which underlined some contradiction on propositions offered in a well-known and much cited in the literature cultural dimension's model:

Students' understanding of the text. 'I stated what I wanted, but I felt uncertain about the story and lost my energy in the end (Sorry!)'.

'I am not sure whether the article is well organized. How evidence-based is the text?'

These comments might indicate as Boghossian (2012) states that what causes perplexity is not the process of the method but the consequence of the truths discovered. Adler (1982) argues that in a Socratic seminar, the use of questions is assumed to underline the learning process since students are put in the position of recognizing their limits knowledge.

However, one student's reflection in relation to comments or questions she shared during the seminar indicates the effect of 'aporia', the outcome of 'elenchus' (Matthews 1999) The discovered truth seemed to puzzle the student to continue the search on the topic:

'The paper is preliminary and has to be extended because there is some evidence missing'.

\section{Protagoras learner characteristics}

Some students' comments showed that during the seminar knowledge that already existed in the class came into the surface, which was used to teach those who do not possess it. Comments made by four students showed that after participating in the seminar, they understood the text (data) better since other students' comments helped them understand the material:

Students' input. 'Yes, it helps to hear other input to form your own opinion'.

'Yes, fellow students explained to me things'.

'Yes, I didn't read it beforehand'.

'Yes, the discussion helped me understand the text better'.

However, students felt they needed their teacher's support to boost their confidence to participate. Students appeared to need the teacher's support when they did not refer to the text in order to offer their argument (2 students) or when they struggled to follow and participate in the seminar in English (2 students):

Teacher's role. 'Lack of teacher involvement, no straight answers given when asked'.

'The teacher didn't contribute much'.

'The speed of the English made it hard to understand (Sorry!)'.

These comments showed that students misunderstood the teacher's role in a Socratic seminar. Perhaps, this behavior can be explained by the fact that these 
students are usually taught within a PBL environment where the tutor's role is to help students do not lose track of the direction the discussion should follow.

Furthermore, two students reported that they had some time constraints for preparing for the seminar and two more noted their lack of interest indicating that the students experienced lack of motivation (Tough 1979 as cited in Knowles 1994, p. 68):

Time constraints and motivation. 'The subject didn't have my attention. I didn't have time to prepare well. When we did know what to expect, I had to make more time for it'.

'I didn't prepare myself the way the class required. I've only read the text once. That's why I couldn't easily join the conversation'.

\section{Gorgias learner characteristics}

Comments made by two students indicated that the conversation helped them to realize that developing critical thinking rather than focusing on any learning theories or concepts was more important. In the reflective journal, for the question 'explain one thing you learned in the seminar from another student', two characteristic comments were:

Critical thinking. 'Be braver to discuss like this. It's a discussion, not a test'.

'The more philosophical way of thinking when exploring different perspectives'

In addition, two students felt that the teacher's experiences, in this case, the teacher's research described in the text given helped them open others to those experiences since they were asked to relate the ideas of the text to real-world applications:

Teacher's input. 'The discussion about tutoring was interesting. Some students could give good arguments why to introduce it to the school system or why not'.

'Tutoring is not only useful in Greece'.

One student's comment in relation to her contribution in the Socratic seminar indicated that the text helped the student compare its content to her personal experiences:

'Cultural differences [during teaching]'.

This student wanted the group to engage in a discussion on different actions and motives in relation to cultural differences. Her comment 'no discussion followed, more like giving group members information on some differences they have experienced' shows that the group discussion left previous assumption on the impact of culture on Greeks' learning behavior during tutorials building further dialogue on a new idea about culture and tutoring presented by a participant. Nevertheless, the sentence 'no discussion followed...' shows that the student was hoping that other students could develop their identificatory reading skills in order to be more apt to take the challenges of life (Trondman 1994, as cited in Pihlgren, 2014, p. 3).

These comments imply that the complex interplay of dialogical and intellectual skills in a Socratic seminar is taught by the assignment of different focus to the methodological steps. Pihlgren (2007) poses the question on whether it is reasonable to think that students in a group voluntarily cooperate to refute the ideas of each other or whether the teacher has to be more actively questioning. In this sense, the role of 
the teacher for a Gorgias learner should be the one of a 'local guide' (Fox 1983) who could help students develop their critical thinking skills and when this is achieved, they could be ready to explore further issues by themselves.

It is worth mentioning that infusing the Greek learning characteristics within the arena of Socratic questioning is only one example of implementing the use of such an approach in teaching.

\section{Some implications and future research}

This article showed that the adult students' learning behaviors were diverse confirming that the teacher should use a multifaceted instructional strategy during a Socratic seminar. Our findings indicated that the Meno learner type students were confused about the questioning technique, the Protagoras learner type expressed their desire to be provided with support by the teacher while the Gorgias learner type seemed to be in favor of a teacher guide, who could help them develop their critical skills. It was also shown that students' reflections indicated that some students exhibited a learning behavior that combined characteristics of the Socratic learner types of Paraskevas' and Wickens' typology.

This result is consistent with Larsen's (2012) concerns, which indicate that, (a) there is diversity in adults' experience, personality and learning style even though they can be defined as one group of learners, and (b) even though adults are selfdirected and responsible for their own learning, interchange of experiences in teaching might be intrusive implying that the teacher should be in control of acknowledging adults' personal attributes.

However, for the majority of the students, the goal setting and outcome of the seminar was a key concern. Students would prefer the teacher to set the table with rules and expectations. Specifically, students felt uncertain criticizing suggested knowledge from well-known and well cited in the literature author publications. In other words, students seemed skeptical to discuss 'transformative academic knowledge'. This knowledge challenges some of the key assumptions that mainstream scholars make about the nature of knowledge as well as some of their major paradigms, findings, theories and interpretations (Banks 1996). This finding indicates that students appeared to struggle to think critically in relation to the topic they were discussing and that students are unable to set the scene of transformational learning (as defined by Mezirow 1991) by constructing the framework of a conversation on a controversial topic by themselves without any specific guidance from the teacher.

Students requested the teacher's help in order to determine the learning goal of the seminar. This is in disagreement with Knowles' andragogy assumption where learner control is a feature of the adult learning situation. The finding indicates that students appeared to be in favor of a mutual relationship between the learner and the educator in managing the learning process. Therefore, our findings suggest that even adults maybe conditioned for a long time to be dependent on their teachers indicating that conditioning a true SDL can take time.

The survey results suggest that students would benefit from activities, for example, discussions on literature reviews on debatable issues that help to clarify the difference 
between academic and transformative academic knowledge prior to the conduct of the seminar. This process could help to promote the value of collective search for truth through further conversation, which reflects Socrates' common ground achieved by 'elenchus' followed by 'aporia'. It could also help to increase students' situational interest and is in with Garisson's (1997) suggestion who argues that teachers should create educational conditions that facilitate self-directed learning. These suggested activities could help to initiate learning goals, a process which is associated with selfdirection (ibid) and could facilitate the process of PBL.

Our findings suggest that a process of negotiating the value of academic and transformative academic knowledge could help set the scene for a successful PBL tutorial. Specifically, both learners and facilitators could discuss criticism on a topic negotiating on the construction of a framework of the topic to be dealt with in a subsequent PBL tutorial. In this way, students could be given responsibility for problem definition and plan of action. Therefore, as described by Garrison (1997, p. 26) 'entering motivation' could be triggered by establishing a commitment to a particular goal and the intent to act. In other words, our findings imply that Socratic questioning is the cause of critical thinking having as an effect the promotion of adults' SDL within a PBL educational context.

Future research on the extent to which such negotiation would be accepted positively by students would prove useful. Specifically, it would be an indicator that other educational processes, for example, the thinking structure of Socratic questioning could be used as a means to increase situational interest and facilitate students' selfdirected learning behavior during the process of PBL learning (Milligan 1999). In this case, it could provide some evidence that Socratic questioning at the outset of PBL could be a strategy within the andragogy model. Milligan (1999) asserts that since andragogy embraces a variety of methods using theory from the literature on selfand student-directness to facilitate learning, then PBL could be a strategy within the andragogy model.

It is important to note though that since this was the first-time students participated in a Socratic seminar and since, as indicated, not many students have prepared the way they should have done, it would be useful to repeat a Socratic seminar in order to be in a position to draw more concrete conclusions. In addition, the authors appreciate that there are some limitations with regard to the sample and the locality of the study that do not allow for generalization for all adult students' response to Socratic questioning during learning and teaching in tertiary education. The sample is restricted to postgraduate students studying in one postgraduate education programme of one of the institutes in the faculty of Humanities in the University of Maastricht. Perhaps, the attitudes of other adult students studying in other postgraduates programmes in other departments in the University of Maastricht or other Dutch or other universities around the world would differ. Also, the current discussion of the study excludes any analysis of gender and cultural differences in terms of attitudes of being taught by the use of Socratic questioning while studying.

\section{Disclosure statement}

No potential conflict of interest was reported by the authors. 


\section{ORCID}

Ourania Katsara (D) http://orcid.org/0000-0002-6261-2841

Kristof De Witte (D) http://orcid.org/0000-0003-0505-8642

\section{References}

Adler, M.J., 1982. The Paideia Proposal. An Educational Manifesto. New York: Collier Books, Macmillan Publishing Company.

Adler, M.J., 1984. The Paideia Program. New York: Macmillan.

Adler, M.J., 1997. How to Speak How to Listen. New York: Touchstone.

Ball, W.H. and Brewer, P.F., 1996. Socratic seminars: Socratic questioning: Then and now. In: R.L. Canady, and M.D. Rettig, eds. Teaching in the block: strategies for engaging active learners. Larchmont, NY: Eye on Education, 29-64.

Ball, W.H., and Brewer, P.F., 2000. Socratic Seminars in the Block. Larchmont, NY: Eye on Education.

Banks, J.A., 1996. Transformative knowledge, curriculum reform, and action. In: J.A. Banks, ed. Multicultural education, transformative knowledge, and action: historical and contemporary perspectives. New York: Teachers College Press, 335-348.

Banning, M., 2005. Approaches to teaching: current opinions and related research. Nurse education today, 25 (7), 502-508.

Barrows, H. S., and Tamblyn, R. M., 1980. Problem-based learning: an approach to medical education. New York: Springer Publishing Company.

Barrows, H.S., 1985. How to design a problem-based curriculum for the preclinical years. New York: Springer.

Barrows, H.S., 2000. Problem-based learning applied to medical education. New York: Springfield, IL: Southern Illinois University Press.

Billings, L., and Roberts, T., 2003. The Paideia seminar: active thinking through dialogue. Chapel Hill, NC: National Paideia Center.

Boghossian, P., 2012. Socratic pedagogy: perplexity, humiliation, shame and a broken egg. Educational philosophy and theory, 44 (7), 710-720.

Burbules, N.C., and Bruce, B.C., 2001. Theory and research on teaching as dialogue. In: V. Richardson, ed. Handbook of research on teaching. Washington, DC: American Educational Research Association, 1102-1121.

Chowning, J.T., 2009. Socratic Seminars in Science class: providing a structured format to promote dialogue and understanding. Science teacher (normal, Ill.), 76 (7), 36-41.

Copeland, M., 2005. Socratic circles: fostering critical and creative thinking in middle and high school. Portland, ME: Stenhouse.

Cresswell, J.W., and Plano, C.V., 2011. Designing and conducting mixed method research. CA: Thousand Oaks.

Daley, B.J., 2003. A case for learner-centered teaching and learning. New directions for adult and continuing education, 2003 (98), 23-30.

Elen, J., and Lowyck, J., 1999. Metacognitive instructional design. Journal of structural learning and intelligent systems, 13 (3-4), 145-169.

Fox, D., 1983. Personal theories of teaching. Studies in higher education, 8 (2), 151-163.

Garrison, D.R., 1992. Critical thinking and self-directed learning in adult education: An analysis of responsibility and control issues. Adult education quarterly, 42 (3), 136-148.

Garrison, D.R., 1997. Self-directed learning: toward a comprehensive model. Adult education quarterly, 48 (1), 18-33.

Hendricson, W.D., et al., 2007. Does faculty development enhance teaching effectiveness? Journal of dental education, 71 (12), 1513-1533. 
Henschke, J.A., 2015. Focusing on the six major themes in the global perspective of andragogy: A June 2015 update. IACE Hall of Fame Repository. Knoxville, TN: University of Tennessee. Available from: http://works.bepress.com/john_henschke/861

Henson, K.T., 2003. Foundations for learner centered education, a knowledge base. Education, $124,5-17$.

Hmelo-Silver, C.E., 2004. Problem-based learning: What and how do students learn? Educational psychology review, 16 (3), 235-266.

Hmelo-Silver, C.E., and Barrows, H.S., 2006. Goals and strategies of a problem-based learning facilitator. Interdisciplinary journal of problem based learning, 1, 21-39.

Hmelo-Silver, C.E., and Eberbach, C., 2012. Learning theories and problem-based learning. In: S. Bridges, C. McGrath, and T.L. Whitehill, eds. Problem-based learning in clinical education. Netherlands: Springer, 3-17.

Hsieh, H.-F., and Shannon, S., 2005. Three approaches to qualitative content analysis. Qualitative health research, 15 (9), 1277-1288.

Jarvis, P., 2004. Adult education and lifelong learning: theory and practice. London: Falmer Press.

Kamin, C.S.P., et al., 2001. Measuring critical thinking in problem-based learning discourse. Teaching and learning in medicine, 13 (1), 27-35.

Katsara, O., 2014. The need to investigate the Greek cultural perspective within the teaching practice of an ESAP class. Asian ESP Journal, 10 (2), 88-113.

Katsara, O., 2018. Implementing tutorials within the context of an English for general academic purposes course in University of Patras: a preliminary study. Research papers in language teaching and learning, 9 (1), 133-148.

Kember, D., et al., 2000. Development of a questionnaire to measure the level of reflective thinking. Assessment and evaluation in higher education, 25 (4), 381-389.

Knežić, D., et al., 2010. The Socratic dialogue in teacher education. Teaching and teacher education, 26 (4), 1104-1111.

Knowles, M.S., 1970. The modern practice of adult education. New York: New York Association Press.

Knowles, M.S., 1975. Self-directed learning. A guide for teachers and learners. Chicago: Follett.

Knowles, M.S., 1980. The modern practice of adult education: from pedagogy to andragogy. Cambridge: Englewood Cliffs.

Knowles, M.S., 1984. The adult learner: a neglected species. Houston, TX: Gulf Publishing.

Knowles, M.S., 1994. A history of the adult education movement in the United States. Melbourne: Krieger Publishing Co.

Knowles, M.S., Holton, E.F., and Swanson, R.A., 1998. The adult learner: the definitive classic in adult education and human resource development. Houston, TX: Gulf Publishing Company.

Lambert, C.L., et al., 2014. Technology and adult students in higher education: a review of the literature. Issues and trends in educational technology, 2 (1), 1-19.

Larsen, L.L., 2012. Pedagogical approaches: insights for teachers of adults. Paper presented at the Norwegian National Graduate School for Teacher Education Network (NAFOL) Conference: teacher education research between national identity and global trends. University of Bergen, Trondheim, Norway. Available from: http://pure.au.dk/portal/files/ 45527673/Pedagogical_Approaches_Insights_For_Teachers_of_Adults_LeaLundLarseb2012. pdf

Lim, L.A.Y.L., 2011. A comparison of students' reflective thinking across different years in a problem-based learning environment. Instructional science, 39 (2), 171-188.

Litman, J.A., 2008. Interest and deprivation factors of epistemic curiosity. Personality and individual differences, 44 (7), 1585-1595.

Lloyd-Jones, G., and Hak, T., 2004. Self-directed learning and student pragmatism. Advances in health sciences education, 9 (1), 61-73.

Matthews, G., 1999. Socratic perplexity and the nature of philosophy. Oxford: Oxford University Press. 
Merriam, S.B., 2004. The role of cognitive development in Mezirow's transformational learning theory. Adult education quarterly, 55 (1), 60-68.

Merriam, S.B., Caffarella, R.S., and Baumgartnerm, L.M., 2007. Learning in adulthood: a comprehensive guide. 3rd ed. San Francisco, CA: Jossey-Bass, 105-129.

Miflin, B., 2004. Adult learning, self-directed learning and problem-based learning: deconstructing the connections. Teaching in higher education, 9 (1), 43-53.

Miller, D., 2008. Learning strategies. In: N.J. Salkind and R. Rasmussen, eds. Encyclopaedia of educational psychology. London: Sage Publications, 955-973.

Milligan, F., 1999. Beyond the rhetoric of problem-based learning: emancipatory limits and links with andragogy. Nurse education Toda, 19 (7), 548-555.

Mezirow, J., 1991. Transformative dimensions of adult learning. San Francisco: Jossey-Bass.

Morrell, K., 2004. Socratic dialogue as a tool for teaching business ethics. Journal of business ethics, 53 (4), 383-392.

National Paideia Center, 2002. Paideia stories: successful schools in practice. The University of North Carolina Chapel Hill: National Paideia Center.

Neville, A.J., 1999. The problem-based learning tutor: Teacher? Facilitator?” Evaluator? Medical teacher, 21 (4), 393-401.

Norman, G.R., and Schmidt, H.S., 1992. The psychological basis of problem-based learning: a review of the evidence. Academic medicine, 67 (9), 557-565.

Oermann, M.H., 2004. Using active learning in lecture: best of both worlds. International journal of nursing education scholarship, 1 (1), 1-9.

Paraskevas, A., and Wickens, E., 2003. Andragogy and the Socratic method: the adult learner perspective. The journal of hospitality leisure sport and tourism, 2 (2), 4-14.

Patton, M.Q., 1990. Qualitative evaluation and research methods. Thousand Oaks, CA: Sage Publications.

Paul, R., and Elder, L., 2007. Critical thinking: the art of Socratic questioning. Journal of developmental education, 31 (1), 36-37.

Paul, R., and Elder, L., 2008. Critical thinking: the art of Socratic questioning, part III. Journal of developmental education, 31 (3), 34-35.

Pihlgren, A.S., 2007. The features of Socratic seminars. In: The 13th International Conference on Thinking Norrköping. Linköping University, Linköping: Linköping University Electronic Press, 159-165.

Pihlgren, A.S., 2014. Thoughtful dialogues and Socratic seminars. Available from: http://igniteresearch.org/wp-content/uploads/2014/10/Thoughtful-Dialogue-and-Socratic-Seminars-Studentsreading-comprehension.pdf [Accessed 13 March 2018].

Potter, W.J., and Levine-Donnerstein, D., 1999. Rethinking validity and reliability in content analysis. Journal of applied communication research, 27 (3), 258-284.

Rachal, J.R., 2002. Andragogy's detectives: a critique of the present and a proposal for the future. Adult education quarterly, 52 (3), 210-227.

Ramsden, P., 1997. The context of learning in academic departments. In: F. Marto, D. Hounsell and N. Entwistle, eds. The experience of learning. Implications for teaching and studying in higher education (pp. 198-217). Edinburgh: Scottish Academic Press.

Roberts, T., and Billings, L., 1999. The Paideia classroom: teaching for understanding. Larchmont, NY: Eye on Education.

Robinson, R., 1971. Elenchus. In: G. Vlastos, ed. The philosophy of Socrates. Notre Dame, Ind.: University of Notre Dame Press, 19-20.

Rogal, S.M., and Snider, P.D., 2008. Rethinking the lecture: the application of problem-based learning methods to atypical contexts. Nurse education in practice, 8 (3), 213-219.

Rotgans, J.I., and Schmidt, H.G., 2012. Problem-based learning and student motivation: the role of interest in learning and achievement. In: J.I. Rotgans and H.G. Schmidt,ed. One-day, one-problem. Singapore: Springer, 85-101.

Rubenson, K., 2011. Adult learning and education. Saint Louis, MO: Academic Press. 
Schmidt, H.G., Rotgans, J.I., and Yew, E.H., 2011. The process of problem-based learning: what works and why. Medical education, 45 (8), 792-806.

Schmidt, H.G., et al., 2009. Constructivist, problem-based, learning does work: a meta-analysis of curricular comparisons involving a single medical school. Educational psychologist, 44 (4), 227-249.

Silén, C., and Uhlin, L., 2008. Self-directed learning-a learning issue for students and faculty. Teaching in higher education, 13 (4), 461-475.

Skinner, V., Braunack-Mayer, A., and Winning, T., 2015. The purpose and value for students of PBL groups for learning. Interdisciplinary journal of problem-based learning, 9 (1), 19-32.

Tough, A., 1979. The adult's learning projects. Canada: The Ontario Institute for Studies in Higher Education.

Trondman, M., 1994. Bilden av en klassresa. [The picture of a social journey]. Stockholm: Carlssons förlag.

Tusting, K., and Barton, D., 2006. Models of adult learning: a literature review. Leicester: NIACE.

Vlastos, G., 1971. The philosophy of Socrates. Notre Dame, Ind.: University of Notre Dame Press.

Wang, H., 2010. The influence of the Socratic tradition on Cambridge practice and its implication on Chinese higher education. Journal of Cambridge studies, 5 (1), 1-18.

Wang, S.Y., et al., 2008. Socrates, problem-based learning and critical thinking-a philosophic point of view. The Kaohsiung journal of medical sciences, 24 (3), S6-S13.

Wilkes, M.S., and Srinivasan, M., 2017. Problem based learning. In: J. Dent, J.R.M. Harden, and D. Hunt, ed. A practical guide for medical teachers. Toronto: Elsevier Health Sciences, 134-142.

Yang, Y.T.C., Newby, T.J., and Bill, R.L., 2005. Using Socratic questioning to promote critical thinking skills through asynchronous discussion forums in distance learning environments. The American journal of distance education, 19 (3), 163-181.

\section{APPENDIX A:}

\section{Seminar questions}

Opening

What is the main idea or underlying value in the text?

What is the author's purpose or perspective?

What does culturally-oriented learning mean?

What is the most important word/sentence or paragraph in the text?

What would be another good title for this text?

Core - focus/analyze textual details

What evidence does the author use to back up her point of view?

Why is the argument structured this way?

What is the relationship between culture and learning?

What does the author mean when she says that the intersection between the tutor role, the learning environment and learning strategies appears to be crucial for Greek students' learning behavior?

Closing - personalize and apply the textual ideas.

How do the ideas in the text relate to our lives?

What do they mean for us personally?

Why is this material important? 


\section{APPENDIX B:}

\section{Seminar Reflection Journal}

1. Gender: (M)ale, (F)emale.

$\mathrm{M}$

$\mathrm{F}$

2. Circle the most accurate response: (N)ever, (S)ometimes, or (A)lways.

N S A I made clear accurate statements.

N S A I referred to the text.

N S A I commented on positive/negative implications of the topic.

N S A I added a global/holistic interpretation to a previous statement.

3. Did you achieve your goal for today? Explain. (Please mention your personal participation goal).

4. In one sentence, summarize what comments or questions you shared. (If you did not participate, explain why you did not?).

5. Discuss one topic you contributed to the seminar. Use your own notes - be sure to explain the topic and contribution.

6. Explain one thing you learned in the seminar from another student - be very specific.

7. In a paragraph, summarize the outcome of the seminar:

(Use these questions to aid your writing: What questions were answered by the class? How? What conclusions were drawn? Do you agree with them? Do you understand them? What disagreements arose? What questions remain unanswered? What questions do you still have?)

8. Do you feel like you understand the text (data) better after participating in the seminar? Why or why not?

9. What did you like most about the seminar and what did you like least? Explain.

10. What do you need to work on in a future seminar? What could become a personal goal for a future seminar?

Follow up activity (Optional): Send your paragraph to okatsara@upatras.gr

Discuss in a paragraph the characteristics of a successful tutor in a problem-based tutorial using the INSPIRE model. 